Pesq. Vet. Bras. 36(8):705-710, agosto 2016 DOI: $10.1590 / \mathrm{S} 0100-736 \mathrm{X} 2016000800005$

\title{
Brucella abortus detected in cheese from the Amazon region: differentiation of a vaccine strain (B19) from the field strain in the states of Pará, Amapá and Rondônia, Brazil ${ }^{1}$
}

\author{
Jacqueline Silva², Carina M. de Moraes², Cleyzer L. Silva², Gustavo A. Sales², Lara B. \\ $\mathrm{Keid}^{3}$, Paulo C.M. Matos ${ }^{2}$, Ana P.S.S. Lara ${ }^{4}$ and Carla C.G. Moraes ${ }^{2 *}$
}

\begin{abstract}
Silva J., Moraes C.M., Silva C.L., Sales G.A., Keid L.B., Matos P.C.M., Lara A.P.S.S. \& Moraes C.C.G. 2016. Brucella abortus detected in cheese from the Amazon region: differentiation of a vaccine strain (B19) from the field strain in the states of Pará, Amapá and Rondônia, Brazil. Pesquisa Veterinária Brasileira 36(8):705-710. Laboratório de Zoonoses e Saúde Pública, Programa de Pós-Graduação em Saúde Animal na Amazônia, Universidade Federal do Pará, BR-316 Km 62, Saudade, Castanhal, PA 68743-050, Brazil. E-mail: ccmoraes@ufpa.br

Brucellosis is an infectious-contagious disease responsible for significant economic losses to the meat and milk supply chain, because it causes reproductive disorders in animals and is a chronic anthropozoonosis. This study was designed to detect the DNA of Brucella spp. in cheese and to differentiate between a vaccine strain (B19) and the field strain. Sixty-six samples of different cheeses which are produced and marketed in three states of the Brazilian Amazon region (Amapá [5 samples], Pará [55 samples] and Rondônia [6 samples]) were evaluated. Thirty-nine of these samples were from cheeses made from cow's milk, and 27 were from cheeses made from buffalo milk. Four of the 66 samples were from cheeses produced in milk processing plants regulated by the Federal Inspection Service (Serviço de Inspeção Federal); nine of the samples were from cheeses produced in processing plants regulated by the State Inspection Service (Serviço de Inspeção Estadual); five of the samples were from artisanal cheeses; and the remaining 48 samples were from informally produced cheese. DNA was obtained from the samples following a DNA extraction protocol, and PCR was conducted using primers B4 and B5 to detect Brucella spp. Primers eri1 and eri2 were used to differentiate the field strain from the B19 vaccine strain. The results showed that $21.21 \%$ (14/66) of the samples were positive for Brucella spp., of which $21.43 \%$ (3/14) were positive for the B. abortus field strain, and $7.14 \%(1 / 14)$ were identified as harboring vaccine strain B19. These results demonstrate that it is possible to identify Brucella spp. in cheese from the Amazon region using the PCR technique and to differentiate the B. abortus field strain from the B19 vaccine strain.
\end{abstract}

INDEX TERMS: Brucella abortus, cheese, cattle, vaccine (B19), PCR.

\footnotetext{
${ }^{1}$ Received on June 17, 2015.

Accepted for publication on May 9, 2016.

${ }^{2}$ Programa de Pós-Graduação em Saúde Animal na Amazônia (PPGSAAM), Universidade Federal do Pará (UFPA), Campus II, BR-316 Km 62, Saudade, Castanhal, PA 68743-050, Brazil. *Corresponding author: ccmoraes@ufpa.br

${ }^{3}$ Faculdade de Zootecnia e Engenharia de Alimentos, Universidade de São Paulo (USP), Av. Duque de Caxias Norte 225, Campus da USP, Pirassununga, SP 13635-900, Brazil.

${ }^{4}$ Laboratório de Imunologia e Parasitologia Molecular, Instituto de Biologia, Universidade Federal de Pelotas (UFPel), Campus Universitário, Capão do Leão s/n, Pelotas, RS 96010-900, Brazil.
}

RESUMO.- [Brucella abortus em queijos na região amazônica: diferenciação em cepa vacinal (B19) ou de infecção a campo nos estados do Pará, Amapá e Rondônia.] A brucelose é uma enfermidade infecto-contagiosa que causa grandes perdas econômicas à cadeia produtiva da carne e do leite, como consequência dos distúrbios reprodutivos nos animais, além de ser uma antropozoonose crônica. O objetivo deste estudo foi detectar DNA de Brucella spp. e fazer a distinção da cepa vacinal (B19) da cepa de infecção de campo. Foram adquiridas 66 amostras de diferentes queijos produzidos e comercializados em três 
estados pertencentes à Amazônia brasileira: Amapá (05), Pará (55) e Rondônia (06), somando 39 amostras de queijo de vaca e 27 de búfala. Deste total quatro eram produzidas em estabelecimentos com fiscalização de Serviço de Inspeção Federal, nove em estabelecimentos com Serviço de Inspeção Estadual, cinco eram de produção artesanal e as demais 48 amostras eram provenientes de produção informal. O DNA das amostras teste foi obtido por um protocolo de extração e a reação em cadeia pela polimerase foi realizada utilizando os oligoiniciadores B4 e B5 para detectar Brucella spp. e, os oligoiniciadores eri1 e eri2 para diferenciar cepa de infecção a campo da cepa vacinal B19. Os resultados mostraram que $21,21 \%$ (14/66) das amostras foram positivas para Brucella spp., destas 21,43\% (3/14) foram positivas para $B$. abortus cepa de campo e $7,14 \%$ $(1 / 14)$ foi identificada como cepa vacinal B19. Concluiu-se que foi possível identificar pela técnica da PCR Brucella spp. em queijos na região amazônica, além de diferenciar as cepas em amostra de B. abortus de infecção a campo ou cepa vacinal B19.

TERMOS DE INDEXAÇÃO: Brucella abortus, queijos, bovídeos, vacina B19, PCR.

\section{INTRODUCTION}

Cheese is one of the most-consumed dairy products in Brazil (Feitosa et al. 2003). Similar to other foods, cheese production must meet hygienic and sanitary standards established under different municipal, state and federal laws (Perry 2004). Milk, which is the raw material for cheese, must come from animals that are raised under proper sanitary conditions to prevent the transmission of microorganisms to consumers through contaminated food. These microorganisms include those of the genus Brucella, which can be excreted for long periods in the milk of infected cows (Zaffari et al. 2007).

Brucellosis is considered endemic in cattle and buffalo herds and is mainly caused by the bacterium Brucella abortus. Brucellosis is an infectious disease that is distributed throughout the world. Its symptomatology includes abortion, retained placenta, birth of weak or stillborn calves and infertility (Nardi Júnior et al. 2012).

Brucellosis is also classified as a chronic anthropozoonosis and can be considered a silent threat to humans because its occurrence is underestimated due to the inadequacy of communication and diagnostic services for animal and human brucellosis (Poester et al. 2002).

Transmission to humans occurs primarily through the ingestion of milk or unpasteurized dairy products that are contaminated with a Brucella species that is pathogenic to humans (Corbel, 2006; Memish \& Balkhy, 2004). Transmission to humans can also result from occupational activities, including inhalation or direct contact with the bacteria during work in laboratories and slaughterhouses, and from accidents when handling vaccines (Campaña et al. 2003).

Brucellosis in humans occurs throughout the world and is characterized by joint disorders, such as degeneration of the skeletal system, that require a long course of treatment (Corbel 2006).
In Brazil, the Ministry of Agriculture, Livestock and Food Supply ("Ministério da Agricultura, Pecuária e Abastecimento" - MAPA) has recognized that brucellosis is an animal and public health problem and is a cause of economic losses to cattle breeders. Thus, the National Program for Control and Eradication of Brucellosis and Tuberculosis ("Programa Nacional de Controle e Erradicação da Brucelose e Tuberculose" - PNCEBT) was published in 2001 with the aim of decreasing the prevalence and incidence of the disease in herds. This program determines strategies for the control and prevention of the disease, which include the elimination of seropositive animals from the herd and vaccination with the B19 strain of all female cattle between the ages of three and eight months (Brasil, 2006). However, the B19 vaccine strain is pathogenic to humans, and there are published reports of accidental infection in veterinarians and vaccinators (Crawford et al. 1990, Ashford et al. 2004, Santos et al. 2005). Pacheco et al. (2012) reported that some animals that had been vaccinated at the prescribed age excreted the B19 vaccine strain intermittently in their milk and urine for up to nine years. They emphasized the importance of assessing the risk of infection by this strain in humans and animals.

Advances in molecular biology techniques have provided tools for the rapid and accurate detection of B. abortus (Öngör et al. 2006, Gupta et al. 2014). Several techniques have been developed, and a 702-base pair (bp) gene deletion can be used as a reference for identifying the B19 vaccine strain (Bricker \& Halling, 1995).

The current study was designed to detect the DNA of Brucella spp. in cheese produced and marketed in the Brazilian states of Amapá, Pará and Rondônia and to differentiate the B19 vaccine strain from the field strain.

\section{MATERIALS AND METHODS}

\section{Samples}

A total of 66 cheese samples from different types of cheese (mozzarella, minas fresh cheese, minas "standard" cheese, provolone, "rennet" cheese, butter cheese, cabacinha cheese and seasoned cheese) were purchased from open markets, industries and supermarkets. Of these samples, 39 were produced from cow milk, and 27 were produced from buffalo milk. The samples were acquired from May 2013 to February 2014 in three states of the Brazilian Amazon: Amapá (05), Para (55) and Rondônia (06). The samples were transported to the laboratory under refrigeration or frozen in their original packaging, and the transport time did not exceed two days. Sample analysis began immediately after arrival at the laboratory.

Four of the samples had been produced from milk from processing plants regulated by the Federal Inspection Service ("Serviço de Inspeção Federal" - SIF); nine of the samples were produced from milk from plants regulated by the State Inspection Service ("Serviço de Inspeção Estadual" - SIE); five of the samples were artisanal cheeses; and the remaining 48 samples came from informal cheese production.

\section{Standard strains (positive control)}

DNA of the Brucella abortus 544 (biovar 1) standard strain and the B. abortus B19 vaccine strain was used in this study.

The B. abortus 544 (biovar 1) DNA was provided by the University of São Paulo (USP), Pirassununga Campus. Its concentra- 
tion was $8.1 \eta \mathrm{g} / \mu \mathrm{l}$, and it was used as a positive control in the PCR assays. DNA had been extracted from the B. abortus 544 (biovar 1) sample using a protocol based on enzymatic lysis and purification with organic solvents, as described by Keid et al. (2007).

The B19 vaccine was commercially acquired from agricultural retailers and was then microbiologically cultured in Thayer-Martin medium and incubated for 48 hours at $37^{\circ} \mathrm{C}$ in a rotary shaker. The culture reached a concentration of $1.4 \times 10^{9} \mathrm{CFU} / \mathrm{ml}$. DNA was extracted from the microbiological culture using an AxyPrep Multisource Genomic DNA Miniprep Kit (Axygen-Biosciences, Republic of China) following the manufacturer's recommendations. A DNA concentration of $88 \mathrm{\eta g} / \mu \mathrm{l}$ was obtained, and the sample was used as a positive control in the PCR assays.

\section{DNA extraction from cheese samples}

DNA was extracted from the test samples using the extraction protocol described by Darwish et al. (2009), as modified by Silva et al. (2015). For DNA extraction, $470 \mu \mathrm{l}$ of STES lysis buffer $(2.42 \mathrm{~g}$ of Tris base, $2.92 \mathrm{~g}$ of $\mathrm{NaCl}, 0.1 \mathrm{~g}$ of SDS and $0.372 \mathrm{~g}$ of EDTA) was added to approximately $0.5 \mathrm{~g}$ of each cheese sample. A glass rod was used to macerate the mixture so that it was homogeneous. An additional $630 \mu \mathrm{l}$ of STES lysis buffer and $10 \mu \mathrm{l}$ of proteinase $\mathrm{K}$ $(20 \mathrm{mg} / \mathrm{ml})$ were added. The mixture was then vortexed for one minute and incubated overnight in a water bath at $55^{\circ} \mathrm{C}$. The next day, $150 \mu \mathrm{l}$ of supernatant was transferred to other microtubes, the same volume of phenol-chloroform was added, and the mixture was vortexed for one minute and centrifuged at 13,000rpm for 10 minutes. The resulting supernatant was transferred to fresh microtubes. DNA was precipitated by adding three volumes of absolute ethanol and one-tenth volume of $3 \mathrm{M}$ sodium acetate. The samples were stored at $-4^{\circ} \mathrm{C}$ for approximately one hour and were then centrifuged again at 13,000 rpm for 30 minutes to obtain the DNA precipitate.

Next, the supernatant was discarded, and the DNA precipitate was washed with $300 \mu \mathrm{l}$ of ice-cold $70 \%$ ethanol. The mixture was centrifuged at 13,000rpm for 5 minutes, after which the supernatant was discarded again, and the microtube was incubated at $37^{\circ} \mathrm{C}$ for 15 minutes to allow the remaining ethanol to be eliminated by evaporation.

The resulting DNA was eluted in $20 \mu \mathrm{l}$ of MilliQ water, analyzed via electrophoresis on a $0.8 \%$ agarose gel stained with ethidium bromide $(0.5 \mu \mathrm{g} / \mathrm{ml})$ and visualized under ultraviolet light in a transilluminator coupled to a photodocumentation system (Quantum-ST4 1000/26M). The DNA was then quantified using a Pico 200 device (Picodrop ${ }^{\mathrm{TM}}$ ).

\section{PCR}

The primers B4 (5'TGGCTCGGTTGCCAATATCAA3') and B5 (5'CGCGCTTGCCTTTCAGGTCTG3') were used for PCR, which amplify a 223-bp fragment of the BCPS gene encoding a 31-kDa immunogenic protein in bacteria of the genus Brucella (Baily et al. 1992). The PCR mixture consisted of $2.5 \mu$ l of $10 x$ PCR buffer (1x), $1.5 \mu \mathrm{l}$ of $\mathrm{MgCl}_{2}(1.5 \mathrm{mM}), 1.0 \mu \mathrm{l}$ of dNTPs $(0.5 \mathrm{mM}), 1.0 \mu \mathrm{l}$ of each primer (5 pmol), $0.4 \mu \mathrm{l}$ of Taq DNA polymerase (5 UI), $2 \mu \mathrm{l}$ of DNA sample $(\sim 436.11 \mathrm{ng} / \mu \mathrm{l})$ and $15.6 \mu \mathrm{l}$ of ultrapure water, in a final volume of $25 \mu \mathrm{l}$.

The temperature cycling program for PCR amplification consisted of an initial denaturation step at $94^{\circ} \mathrm{C}$ for 5 minutes, followed by 40 cycles of three steps: denaturation at $94^{\circ} \mathrm{C}$ for 60 seconds, annealing at $63^{\circ} \mathrm{C}$ for 60 seconds and extension at $72^{\circ} \mathrm{C}$ for 60 seconds. There was a final extension step at $72^{\circ} \mathrm{C}$ for 10 minutes.

The primers eri1 (5'GCGCCGCGAAGAACTTATCAA3') and eri2 (5'CGCCATGTTAGCGGCGGTGA3') were used for differentiating the B. abortus B19 vaccine strain from the field strain. These pri- mers amplify a 361-bp product for the B19 vaccine strain and a 178-bp product for the B. abortus field strain (Bricker \& Halling 1995). The amplification mixture consisted of $2.5 \mu \mathrm{l}$ of $10 \mathrm{x}$ PCR buffer $(1 \mathrm{x}), 1.5 \mu \mathrm{l}$ of $\mathrm{MgCl}_{2}(1.5 \mathrm{mM}), 1.0 \mu \mathrm{l}$ of dNTPs $(0.2 \mathrm{mM}), 1 \mu \mathrm{l}$ of each primer (10pmol), $0.5 \mu \mathrm{l}$ of Taq DNA polymerase (5 UI), $2 \mu \mathrm{l}$ of DNA sample $(\sim 436.11 \mathrm{ng} / \mu \mathrm{l})$ and $15.5 \mu \mathrm{l}$ of ultrapure water. The temperature cycling program for PCR amplification consisted of an initial denaturation step at $94^{\circ} \mathrm{C}$ for 5 minutes, followed by 40 cycles of three steps: denaturation at $94^{\circ} \mathrm{C}$ for 60 seconds, annealing at $51^{\circ} \mathrm{C}$ for 60 seconds and extension at $72^{\circ} \mathrm{C}$ for 60 seconds. There was a final extension step at $72^{\circ} \mathrm{C}$ for 10 minutes.

The DNA of the B. abortus 544 strain and the B19 vaccine strain was used as a positive control in the PCR assays, and nuclease-free water was used as a negative control.

All the amplification reactions were performed in a Veriti 96Well Thermal Cycler (Applied Biosystems), and the PCR products were analyzed via electrophoresis on a $1.5 \%$ agarose gel stained with ethidium bromide $(0.5 \mu \mathrm{g} / \mathrm{ml})$ and visualized under UV light in a transilluminator coupled to a photodocumentation system (Quantum-ST4 1000/26M).

\section{RESULTS AND DISCUSSION}

The 223-bp fragment was amplified in 14 of the 66 (21.21\%) cheese samples tested with primers B4 and B5, which indicated the presence of genetic material from an organism of the Brucella genus (Fig.1). The samples that were positive for Brucella spp. were also tested with primers eri1 and eri2. The 178-bp fragment was amplified in $21.43 \%$ (3/14) of these samples, which showed that the samples contained DNA from the Brucella abortus 544 field strain. The 361-bp fragment was amplified in 7.14\% (1/14) of these samples, which showed that the sample contained DNA from the B. abortus B19 vaccine strain (Fig.2).

Miyashiro et al. (2007), who evaluated 192 samples of cheese that had been informally produced in two states in southeastern Brazil, reported results similar to those of the present study. They found that $19.27 \%$ (37/192) of the samples were positive. Kobayashi (2012), who evaluated 43 samples of cheeses that were informally produced in the southeastern region of Brazil, detected only $11.63 \%$ (5/43) positive samples. Miyashiro et al. (2007) and Kobayashi (2012) also used primers B4 and B5 for the detection of Brucella spp.

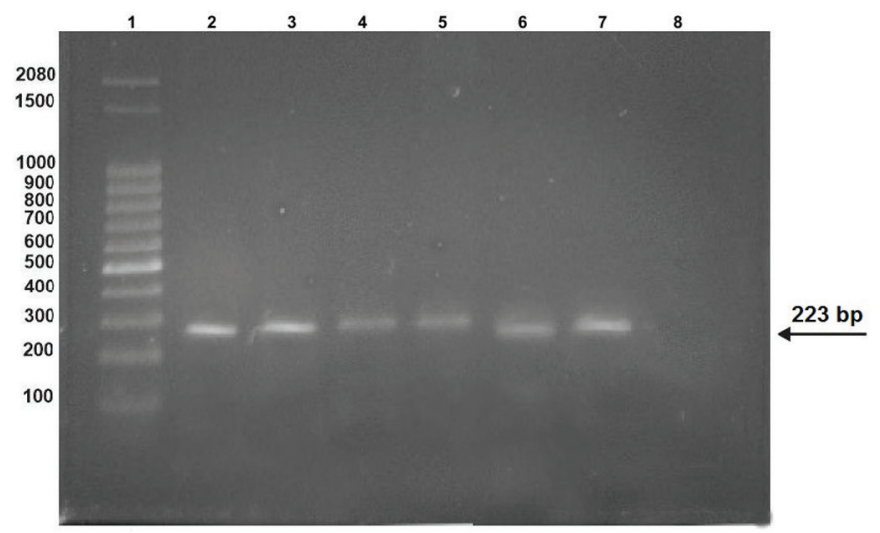

Fig.1. Electrophoretic profile of amplicons from a PCR assay to detect Brucella spp. using primers B4 and B5 in a 1.5\% agarose gel. (01) $100 \mathrm{bp}$ molecular weight marker; (02) B. abortus 544; (03) B19 vaccine strain; (04-07) cheese samples; (08) negative control. 
Farrokh \& Farrokh (2013) used primers B4 and B5 to analyze 60 cheese samples marketed in Iran and found that $13.33 \%(8 / 60)$ of the samples were positive for Brucella spp., a rate lower than that obtained in the present study. In turn, Arasoğlu et al. (2013) reported that 82\% (273/334) of tested samples were positive for Brucella spp. in a study conducted in Turkey; this high rate may be explained by the status of Turkey as an endemic country for brucellosis.

Primers eri1 and eri2 generated different results from those reported by Miyashiro et al. (2007), who found that $81.08 \%(30 / 37)$ of tested cheese samples were positive for the B19 vaccine strain and $18.92 \%$ (7/37) were positive for the field strain. The higher percentage of samples positive for the vaccine strain was most likely due to the intermittent excretion of this strain, which usually occurs in mammary lymph nodes. There is a higher rate of excretion during the estrus period and after parturition, when there is a long lactation period, resulting in a risk to public health (Pacheco et al. 2012).

Öngör et al. (2006) evaluated 40 samples of illegally made cheese in Turkey (30 of the samples were cheeses made from sheep's milk, and 10 had been made from cow's milk). They detected B. abortus in 5\% (2/40) of the cheese samples using primers BAB and IS711, which amplify a 498-bp fragment. This percentage is lower than those

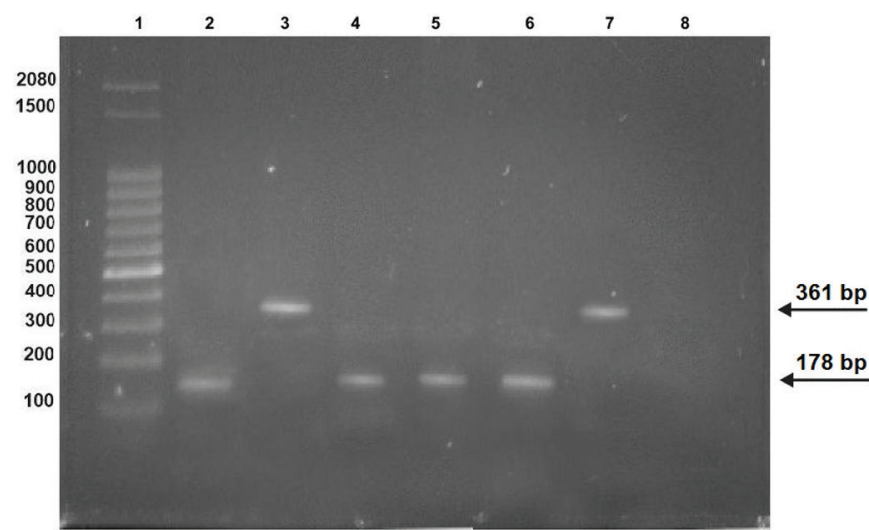

Fig.2. Electrophoretic profile of amplicons from a PCR assay to differentiate the DNA of the Brucella abortus B19 vaccine from a field strain using primers eri1 and eri2 in a 1.5\% agarose gel. (01) 100 bp molecular weight marker; (02) B. abortus 544; (03) B19 vaccine strain; (04-07) cheese samples; (08) negative control.

Table 1. Distribution of the positive polymerase chain reaction (PCR) results from cheese samples originating from the states of Pará, Amapá and Rondônia, Brazil

\begin{tabular}{lcccc}
\hline Sample & Origin & $\mathrm{n}$ & $\mathrm{B} 4$ and B5 & eri 1 and eri 2 \\
\hline Cow cheese & Informal & 33 & 5 & 3 (B. abortus) \\
& SIE & 5 & - & - \\
\multirow{3}{*}{ Buffalo cheese } & SIF & 1 & - & - \\
& Artisan & 5 & 2 & - \\
& Informal & 15 & 4 & $1(\mathrm{~B} 19)$ \\
Total & SIE & 4 & 2 & - \\
& SIF & 3 & 1 & - \\
\hline
\end{tabular}

SIE = State Inspection Service (Serviço de Inspeção Estadual); SIF = Federal Inspection Service (Serviço de Inspeção Federal). found in the current study, which may have been due to the use of different primers.

In the present study, 39 of the cheese samples had been produced from cow's milk (Table 1). Of these samples, 33 had been informally produced, among which $15.15 \%$ (5/33) were positive for Brucella spp. However, only three of the five positive samples were identified as harboring the B. abortus field strain. No Brucella DNA was observed in the cow's milk cheeses produced from milk from processing plants that were regulated by official inspection services, which conforms to the required sanitary quality standards and reinforces the importance of legislation prescribing sanitary standards for animal products.

In the present study, 27 of the cheese samples had been produced from buffalo milk (Table 1). Five of these samples were labeled as artisanal products, and $40 \%$ of these samples $(2 / 5)$ produced amplicons when primers B4 and B5 were used. Fifteen of the 27 buffalo milk samples were from cheese that was informally produced, and $26.67 \%$ of these samples (4/15) were positive for Brucella spp. Only one of these four samples was confirmed to harbor the B19 vaccine strain. Four of the samples of buffalo milk cheese had been produced from milk from plants that were supervised by an official inspection service. One-half $(50 \%, 2 / 4)$ of the samples produced from milk from plants that were supervised by the State Inspection Service produced amplicons when primers B4 and B5 were used. One of three (33.3\%) of the buffalo milk cheese samples produced from milk from plants that were supervised by the Federal Inspection Service produced amplicons when primers B4 and B5 were used. However, we cannot allege any nonconformity in the quality control of the milk processing plants because it is not possible to determine whether the detected strain is a field or vaccine strain when primers B4 and B5 are used. This limitation suggests that other primers should be used or that the detected Brucella spp. should be sequenced.

In 10 of the 14 cheese samples that were positive for Brucella spp., neither the DNA of the B19 vaccine strain nor that of the B. abortus field strain could be identified (Table 1 ), which suggests that the detected amplicons were from another species of the genus Brucella that was not targeted in the current study. Moreover, we cannot rule out the possibility that these discrepant results are due to differences in the sensitivity of the primers. Sequencing of the amplicons from the eri-PCR-negative samples could clarify these issues.

We also found that DNA of neither the vaccine strain nor the field strain was detected in $78.79 \%(52 / 66)$ of the samples, suggesting that these products were free of the pathogen at the time of production or that product processing conditions (such as temperature, salt or maturation time) may have degraded the bacterial DNA. We can also suggest other factors as causes of bacterial infection, such as an abundant bacterial load released into the infected animal's milk during pregnancy (bacteria migrates to the uterus, which is the site of major tropism); however, the bacteria are not released in non-pregnant females and are thus insufficient for detection in cheese by PCR analysis, likely justifying the number of negative samples. Another possibility would be that milk from more than one animal 
was mixed to produce a single piece of cheese, which decreases the genetic material of the investigated strains. Thus, we emphasize the importance of performing microbiological cultures to demonstrate the biological feasibility of the agent in the samples used for the PCR analysis, which could not be conducted because the territorial dimensions of the Amazon region required most of the samples to be transported frozen to the laboratory.

The presence of this bacterium in chesses may represent a risk to the health of consumers (Crawford et al. 1990). Some studies have shown PCR identification to be a more efficient means of detecting this microorganism compared to microbiological cultivation because very low concentrations of Brucella spp. are required, and the same has not to be feasible in the food, besides being a relatively fast technique. In a study conducted in Italy that compared microbiological cultivation and PCR in cheese and milk artificially contaminated with $B$. melitensis, Tantillo et al. (2001) showed that PCR was able to detect the agent in food, even at very low concentrations (under 10 UFC). Accordingly, Miyashiro et al. (2007) were unable to isolate the agent in any sample of cheese, whereas PCR successfully identified genetic material of B. abortus in $19.7 \%$ of the samples.

However, because only one sample was identified as the vaccine strain, we can suggest that the $B 19$ vaccine strain is excreted through the female's milk. According to a report by Pacheco et al. (2012), the intermittent elimination of this strain can happen in milk until the animal is nine years old, with peaks during estrus periods, up to 150 days of pregnancy and postpartum. In view of these facts, it is necessary to assess the elimination period of this strain in the milk of immunized animals at the age recommended by the PNCEBT and to assess the occasional risk of infection to susceptible animals and to humans, especially consumers of milk and its by-products. However, when assessing the persistence of strain B19 in the blood circulation up to one year after the vaccination of 48 calves, Umeda (2014) found that PCR was inefficient compared to serology for the identification of this strain in the bloodstream.

The circulation of this pathogenic agent among dairy herds in the Amazon region can be explained by the acquisition of carrier animals, the proximity of infected herds and the survival capacity of this bacterium in the environment when eliminated during abortion or delivery (Crawford et al. 1990).

Although the data on the detection of DNA from the $B$. abortus field strain and vaccine strains in samples of cheeses are insipient, we conclude that this research represents a unique work in the Amazon region because it demonstrates the possibility of detecting DNA of B. abortus in samples of cheese. However, the negative results do not exclude the possibility of excretion of the field strain and vaccine strain through milk. It is necessary to characterize the true epidemiologic situation of this pathogen in cheeses of the Brazilian Amazon.

Acknowledgments.- The authors are grateful for the support of the Dean of Research and Graduate Studies ("Pró-Reitoria de Pesquisa e Pós-Graduação" - Propesp) and the Foundation for the Support and Development of Research ("Fundação de Amparo e Desenvolvimento da Pesquisa" - Fa- desp) under Research Project Call Number 01/2014 of the Program for the Support of Qualified Publications ("Programa de Apoio à Publicação Qualificada" - PAPQ), and we thank the Brazilian Federal Agency for the Support and Evaluation of Graduate Education ("Coordenação de Aperfeiçoamento de Pessoal de Nível Superior" - CAPES) for granting a Master's scholarship.

\section{REFERENCES}

Ashford D.A., Di Pietra J., Lingappa J., Woods C., Noll H., Neville B., Weyant R., Bragg S.L., Spiegel R.A., Tappero J. \& Perkins B.A. 2004. Adverse events in humans associated with accidental exposure to the livestock brucellosis vaccine RB51. Vaccine 22:3435-3439.

Arasoğlu T., Güllüce M., Özkan H., Adigüzel A. \& Şahin F. 2013. PCR detection of Brucella abortus in cow milk samples collected from Erzurum, Turkey. Turkish J. Med. Sci. 43:501-508.

Baily G.G., Krahn J.B., Drasar B.S. \& Stoker N.G. 1992. Detection of Brucella melitensis and Brucella abortus by DNA amplification. J. Trop. Med. Hygiene 95:271-275.

Brasil 2006. Programa Nacional de Controle e Erradicação da Brucelose e da Tuberculose Animal (PNCEBT): manual técnico. Ministério da Agricultura, Pecuária e Abastecimento, MAPA/SDA/DAS, Brasília. 188p.

Bricker B.J. \& Halling S.M. 1995. Enhancement of the Brucella AMOS PCR assay for differentiation of Brucella abortus vaccine strains S19 and RB51. J. Clin. Microbiol. 33:1640-1642.

Campaña R.C., Gotardo D.J. \& Ishizuka M.M. 2003. Epidemiologia e profilaxia da brucelose bovina e bubalina. [Epidemiology and prevention of bovine and buffalo brucellosis]. Coordenadoria de Defesa Agropecuária de São Paulo [Department of Agricultural Defense of São Paulo].

Corbel M.J. 2006. Brucellosis in Humans and Animals. Library Cataloguing in Publication Data, World Health Organization, Geneva. 102p.

Crawford R.P., Huber J.D. \& Adams B. 1990. Epidemioly and surveillance, p.131-151. In: Nielsen K. \& Duncan J.R. (Eds), Animal Brucellosis. CRC Press, Boca Raton, Florida.

Darwish S.F., Allam H.A. \& Amin A.S. 2009. Evaluation of PCR assay for detection of cow's milk in water buffalo's milk. World Appl. Sci. J. 7:461-467.

Farrokh A. \& Farrokh A.R. 2013. Evaluation of PCR, culture and serology methods for the detection of Brucella spp in fresh cheese samples. Int. J. Agron. Plant Prod. 4:319-323.

Feitosa T., Borges M.F., Nassu R.T., Azevedo E.H.F. \& Muniz C.R. 2003. Pesquisa de Salmonella sp., Listeria sp. e microrganismos indicadores higiênico-sanitário em queijo de coalho produzido no Estado do Rio Grande do Norte [Salmonella sp., Listeria sp. and hygienic sanitary indicator microorganisms in cheeses from Rio Grande do Norte state]. Ciênc. Tecnol. Alimentos 23(Supl.):62-165.

Gupta V.K., Nayakwadi S., Kumar A., Gururaj K., Kumar A. \& Pawaiya R.S. 2014. Markers for the molecular diagnosis of brucellosis in animals [Approaches in diagnosis and management of diseases of livestock and poultry]. Adv. Anim. Vet. Sci. 2:31-39. (Special issue 3)

Keid L.B., Soares R.M., Vieria N.R., Megid J., Salgado V.R., Vasconcellos S.A., Da Costa M., Gregori F. \& Richtzenhain L.J. 2007. Diagnosis of canine brucellosis: comparison between serological and microbiological tests and a PCR based on primers to 16S-23S rDNA interspacer. Vet. Res. Commun. 31:951-965.

Keppie J., Williams A.E., Witt K. \& Smith H. 1964. The role of erytritol in the tissue localization of the Brucellae. Brit. J. Exp. Pathol. 46:104-108.

Kobayashi P.F. 2012. Monitoramento dos principais agentes zoonóticos em leite e seus derivados de origem clandestina, provenientes de animais criados às margens do Rio Tietê, São Paulo, Brasil [Screening of the main zoonotic agents in uninspected milk and dairy products obtained from animals raised on the margins of the Tietê river, São Paulo]. Master's Dissertation on Health, Food Safety and Environmental Agribusiness. Instituto Biológico, São Paulo, SP. 61p.

Memish Z. \& Balkhy H. 2004. Brucelosis and international travel. J. Travel Med. 11:49-55. 
Miyashiro S., Scarcelli E., Piatti R.M., Campos F.R., Vialta A., Keid L.B., Dias R.A. \& Genovez M.E. 2007. Detection of Brucella abortus DNA in illegal cheese from São Paulo and Minas Gerais, and differentiation of B19 vaccinal strain by means of the Polymerase Chain Reaction (PCR). Braz. J. Microbiol. 38:17-22.

Nardi Júnior G., Ribeiro M.G., Paulin L. \& Jorge A.M. 2012. Brucelose em bubalinos: uma revisão com ênfase ao sorodiagnóstico oficial [Brucellosis in buffaloes: a review with emphasis on official serodiagnosis]. Vet. Zootec. 19:142-156.

Öngör H., Çetinkaya B., Karahan M. \& Bulut H. 2006. Evaluation of immunomagnetic separation polymerasechain reaction in direct detection of Brucella abortus and Brucella melitensis from cheese samples. Foodborne Pathogens and Disease 3:245-250.

Pacheco W.A., Genovez M.E., Pozzi C.R., Silva L.M.P., Azevedo S.S., Did C.C., Piatti R.M., Pinheiro E.S., Castro V., Miyashiro S. \& Gambarini M.L. 2012. Excretion of Brucella abortus vaccine B19 strain during a reproductive cycle in dairy cows. Braz. J. Microbiol. 43:594-601.

Perry K.S.P. 2004. Queijos: aspectos químicos, bioquímicos e microbiológicos [Cheese: chemical, biochemical and microbiological aspects]. Química Nova 27:293-300.

Poester F.P., Gonçalves V.S.P. \& Lage A.P. 2002. Brucellosis in Brazil. Vet. Microbiol. 90:55-62.
Santos R.L., Silva F.L., Paixão T.A. \& Samartino L.E. 2005. Brucelose: zoonose e bioterrorismo [Brucellosis: zoonosis and bioterrorism]. Cadernos Técnicos de Veterinária e Zootecnia 47:83-98.

Silva C.L., Sales G.A., Santos Neto J.G., Silva J.S., De Lara A.P.S.S., Lima S.C.G., Leite F.P.L., Nunes E.S.C.L., Moraes, C.C.G., Roos T.B. \& Moraes C.M. 2015. Detecção de fraude em amostras comerciais de queijo bubalino por adição de leite bovino por meio da técnica de Reação em Cadeia da Polimerase (PCR) multiplex [Fraud detection in commercial samples of buffalo cheese by addition of bovine milk using multiplex polymerase chain reaction (PCR)]. Revta Inst. Adolfo Lutz, São Paulo, 74:21-29. (Impresso)

Tantillo G., di Pinto A., Vergara A. \& Buonavoglia C. 2001. Polymerase chain reaction for the direct detection of Brucella spp. in milk and cheese. J. Food Protection 64:164-167.

Umeda L.M.L. 2014. Avaliação da persistência da vacina B19 pelo Teste do Antígeno Acidificado Tamponado e PCR em bezerras vacinadas [Evaluation of vaccine B19 persistence using the Buffered Acidified Antigen test and PCR in vaccinated calves]. Master's Dissertation in Animal Science, Federal University of Mato Grosso do Sul, Campo Grande, MS. 49p.

Zaffari C.B., Mello J.F. \& Costa M. 2007. Qualidade bacteriológica de queijos artesanais comercializados em estradas do litoral norte do Rio Grande do Sul, Brasil [Bacteriological quality of homemade cheeses commercialised on roads of the northern coast of Rio Grande do Sul, Brazill. Ciência Rural 37:862-867. 